\title{
Maaseudun ja kaupungin vuorovaikutus tutkimuskohteena
}

\author{
Torsti Hyyryläinen
}

DOI: $10.51807 /$ maaseutututkimus. 112885

$\mathrm{K}$

aupunki ja maaseutu ovat useimmille meistä ilmiöinä ja sanoina tuttuja. Kulttuuristen merkitysten ja koodien omaksumisen myötä osaamme suhteellisen yksituumaisesti tulkita erilaisia paikkoja kaupunki- tai maaseutuympäristöinä. Ymmärryksemme niistä on rakentunut kollektiivisesti, vaikka teemme niistä myös omakohtaisia tulkintoja.

Maaseudut ja kaupungit ovat arjen elämisen paikkoja. Ne eivät kuitenkaan ole vain fyysisiä elinympäristöjä, vaan myös abstrakteja olioita ja kulttuurisia merkitysjärjestelmiä, joista viestimme eri muodoin, kuten kielen kautta. Sekä maaseudusta että kaupungista puhutaan usein yleistäen, vaikka toisaalta tiedetään, että nämä kategoriat sisältävät aineksia hyvin erilaisten kaupunkien ja maaseutujen erityislaatuisista paikallisista todellisuuksista.

Niin kaupungit kuin maaseudut voidaan siis ymmärtää fyysisten, yhdyskuntarakenteen ilmentämien maantieteellisten muotojensa lisäksi kulttuurisesti tuotetuiksi tiedollisiksi konstruktioiksi, joiden käyttöä ja tulkintaa määrittävät kunkin aikakauden kulttuureissa jaetut käsitykset, kuvaukset ja merkitykset. Koska maaseutu ja kaupunki ovat jatkuvasti muuntuvia olioita, niiden suhdekaan ei voi olla staattinen.

Maaseudun ja kaupungin vuorovaikutus - vaikuttaminen toisiinsa nousee itsessään harvoin puheenaiheeksi. Näin siitä huolimatta, että olemme päivittäin lukemattomilla tavoilla tekemisissä tähän suhteeseen liittyvien asioiden ja ilmiöiden kanssa. Edes elämän välttämättömyyksistä, 
kuten esimerkiksi ruuasta, ei puhuta maaseudun ja kaupungin vuorovaikutuksena.

On ilmeiset historialliset syynsä siihen, että vuorovaikutusta on useammin lähestytty kaupunkien näkökulmasta ja kaupungistumisen prosessin kautta. Onhan niin, että vasta kaupunkien synty loi tarpeen maaseudun määrittelylle. Kielen ilmaisut kehittyivät siten myöhemmin kuvaamaan kaupunkien rajojen ulkopuolisia alueita kaupungeista erillisenä entiteettinä - maaseutuna. Määritelmälliset rajanvedot näiden olioiden välillä eivät ole lainkaan yksiselitteisiä.

Vanhastaan kaupunki-sanasta erottunut sana on kylä. Kylän käsite ei kuitenkaan ollut riittävä kuvaamaan yleisesti kaupungeista erottuvia laajempia alueita. Kiinnostava näkökulma maaseudun ja kaupungin vuorovaikutukseen syntyy tarkasteltaessa kylää, joka on läheisen kaupungin kasvun myötä "sulautunut" kaupunkiin ja tullut hallinnollisesti sen osaksi. Elävänä yhteisönä tällainen yhdyskunta voi myös kaupungin osana säilyttää pitkään sekä fyysisiä että kulttuurisia erityispiirteitään.

Edustaako mainittu kaupunginosaksi määritelty kylä sitten maaseutua kaupungin sisällä? Tai millaiset kylät lopulta ovat osa maaseutua? Määrittelyjen vaikeudesta ja tulkinnallisuudesta voi nykyajan esimerkkinä mainita hiihtokeskukset ja lomakylät. Kyselytutkimuksen mukaan vain 12 \% suomalaisista pitää turismin varassa toimivia pohjoisen hiihtokeskuksia maaseutuna (Pyysiäinen \& Vihinen 2020). Näissä keskuksissa onkin paljon kaupunkielämän piirteitä, jotka erottavat ne pidemmän historian aikana muotoutuneista maaseutukylistä, mutta siitä huolimatta niitä tuskin tulkitaan myöskään kaupungeiksi.

Pitkälti onkin kyse siitä, miten erilaisia yhdyskuntarakenteita kullakin aikakaudella määritellään ja kuvataan tiettyjä käsitteitä ja suureita käyttämällä. Näiden rakenteiden muuttuessa syntyy myös tulkinnanvaraisuutta sekä jännitteisyyttä, jotka heijastuvat kieleen ja yhteiskunnallisiin keskusteluihin. Suomen kieleen maaseudun käsite on vakiintunut suhteellisen myöhään muodostaen samalla vastakohdan kaikille kaupungeille yleensä. Tällainen abstraktien kategorioiden muotoutuminen on tehnyt mahdolliseksi ymmärtää kaupungin ja maaseudun entiteetit itsenäisinä ja toisistaan erottuvina käsitteinä, joka puolestaan mahdollistaa myös niiden vuorovaikutuksesta puhumisen. 
Maaseudun ja kaupungin suhteen tarkastelun kannalta onkin tärkeätä, että molemmat osapuolet (entiteetit) otetaan huomioon. Vaikka kaupunki on tämän julkaisun teksteissä vahvasti läsnä, artikkeleissa tuota suhdetta tarkastellaan tarkoituksella maaseutua painottaen. Maaseudun ja kaupungin suhde on maailmanlaajuinen kysymys. Esimerkiksi meidän suomalaisten kuluttamisen vaikutukset näkyvät monien mantereiden maaseuduilla, vaikka emme sitä jokapäiväisessä elämässä useinkaan tiedosta.

Kyse on siis globaalista teemasta. Tämän julkaisun artikkelit sijoittuvat kuitenkin suomalaiseen kontekstiin erityisesti siitä syystä, että niiden empiiriset aineistot (suomenkieliset sanomalehtikirjoitukset) koskevat Suomea. Olisi täysin mahdollista nostaa minkä tahansa tämän julkaisun artikkelin tutkimuskysymys kansainväliseksi tutkimusasetelmaksi.

\section{Kaupungin ja maaseudun olemuksen määrittelemisestä}

Kaupunkikulttuurin historia on usean tuhannen vuoden pituinen. Käsitteenä kaupunki on huomattavan paljon vanhempi kuin maaseutu. Tämä koskee ilmeisesti useimpia maailman kieliä, joissa näitä sanoja ilmenee. Suomen kieleen sana kaupunki tuli Mikael Agricolan myötä 1500-luvulla, kun taas sana maaseutu tuli suomen kirjoitettuun kieleen vasta 1800luvun puolivälissä. Tämä ei luonnollisesti tarkoita, etteikö näitä entiteettejä olisi kuvattu tai ettei niihin viittaavia asioita olisi sanoitettu muilla tavoilla ja termeillä ennen mainittuja ajankohtia, mutta jäsentyvää ymmärrystä näiden termien ympärille ei ole voinut kertyä ennen sanojen vakiintumista kieliyhteisön käyttöön. ${ }^{1}$

Elinympäristöinämme kaupungit ja maaseudut ovat olleet niin kauan, että on käytännössä lähes mahdotonta etäännyttää itsemme ulkopuolisiksi niiden tarkastelussa. Tästä kerrostuneesta tuhatvuotisesta historiasta, jaetusta kokemuksesta, kerronnasta ja kuvastosta ei myöskään voi koota synteesiä. Se on itsessään synteesi, jossa esitykset kaupungeista ja maaseuduista ovat sulautuneet kollektiivisiksi tulkinnoiksi, osaksi nykyihmisen tietoisuutta, elämää ja kieltä. Eri kulttuureissa ja eri aikakausina näillä kuvauksilla on kiistaton, joskin vaihteleva vaikutus siihen, miten ymmärrämme ja tulkitsemme erilaisia alueita ja paikkoja, kuten kaupunkeja ja maaseutuja, sekä niiden asemaa yhteiskunnassa.

1 Katso aiheesta tarkemmin Kanner \& Hyyryläinen 2021 tässä teoksessa. 
Koska kaupunkiin ja maaseutuun sisältyy mittaamattoman paljon inhimillistä kokemusta ja tunnetiloja, taiteella on niiden kuvaamisessa tärkeä roolinsa. Niin kaupunkikulttuuri kuin elämä maaseudulla ovat olleet kirjallisuuden, maalaus-, valokuva-, elokuva- ym. taiteiden kohteina hyvin pitkään. Tämä kuvasto on muovannut käsitystämme kaupungin olemuksesta sekä elämästä maaseudulla. Taiteellista ilmaisua on eri aikoina käytetty myös tarkoituksellisesti, esimerkiksi synnyttämään yhteistä tulkintaa "kotimaasta" ja kansakunnasta. Tämän kerronnan ja kuvaston läpikäyminen olisi itsessään (pelkästään Suomea koskien) erittäin laaja tutkimustehtävä. Tässä yhteydessä on tyydyttävä toteamaan, että juuri tämä monipuolinen kiinnostus näihin entiteetteihin on pitänyt myös maaseudun ja kaupungin käsitteet hyvin elinvoimaisina ja käyttökelpoisina.

Kaunokirjallisuudesta löytyy monia tarkkanäköisiä kuvauksia niin erilaisista kaupungeista kuin maaseuduista. Taiteilijan "tutkimustyöstä" olkoon esimerkkinä runoilija Matti Paavilaisen kokoelma Kaupunki enemmän kuin kohtalo (1972). Sen esittelyssä todetaan Paavilaisen tutkineen lyyrisin keinoin, miten kaupunki ja ihminen ovat vuorovaikutuksessa keskenään ja vaikuttavat toisiinsa. Paavilaisen mukaan kaupunki ilmentää moninaisuutta, josta kumpuaa jatkuva ristiriita. Ihmisen elinympäristönä kaupunkia ei ensisijaisesti muovaa luonto, vaan ihmisen luova toiminta, jonka tulokset näkyvät kaupunkiympäristössä (Paavilainen 1972, 18-19). Paavilaisen runoissa näkyy myös 1970-luvun Suomessa tyypillinen suhde maaseutuun: se on jotain kaupungistumisen jalkoihin ja taakse jäänyttä.

Historian näkökulmasta kaupunki voidaan nähdä tilallisena ilmauksena kunkin aikakauden sivilisaation perimmäisistä arvoista ja pyrkimyksistä (Joutsivuo \& Kekäläinen 2005, 10). Kaupunkien rakentuminen uskonnollisen (sakraalisen), poliittisen ja kaupallisen tilan yhdistäviksi kokonaisuuksiksi on luonut vankan perustan niiden valta-asemalle ja hegemonialle suhteessa kaupunkeja ympäröivään maaseutuun ja maaseutumaiseen elämäntapaan (emt., 11-16).

Molemmat tarkastelemamme entiteetit hylkivät tarkkoja määritelmiä. Niitä on kuitenkin ollut tarpeen määritellä, ei vain arkisten keskustelujen sujuvuuden vaan erityisesti hallinnon, tilastoinnin ja yhteiskuntapolitiikan eri sektorien tarpeisiin. Selkeämmin perusteltaviin määrittelyihin on pyritty tutkimuskirjallisuudessa. Tieteelliset julkaisut eivät ole määrällisesti suurin maaseutu- tai kaupunkikuvausten lajityyppi, mutta 
systemaattisen luonteensa vuoksi se on todennäköisesti ollut hyvin vaikuttava.

Tieteen ja erityisesti yhteiskuntatieteiden suhde kaupunkiin ja maaseutuun on myös itsessään kiinnostava kysymys. On hyvät perusteet todeta, että kaupungistumisella on ollut suuri vaikutus monien tieteenalojen kehitykseen. Se vauhditti 180o-luvun lopulla muun muassa sosiaalitilastollisten menetelmien kehitystä sekä vaikutti esimerkiksi modernin sosiologian vakiintumiseen tieteenalana. Yhteiskunnan modernisaatio kiinnosti useita 1800-1900 -lukujen vaihteen suuria nimiä. Sosiologian klassikko Émile Durkheim (1858-1917) kiteyttää yhdessä pääteoksistaan, Sosiaalisesta työnjaosta (1990, [1893]), miten yhteiskunnan jatkuva kehitys monimuotoisemmaksi tuottaa pidemmälle kehittynyttä työnjakoa ja orgaanista solidaarisuutta, jotka muodostavat modernin yhteiskunnan kehityksen moraalikoodiston keskeisen perustan.

Työnjaon kehittymisen perustavaa syytä on Durkheimin (emt., 237) mukaan "etsittävä sosiaalisen miljöön tietyistä vaihteluista". Samalla hän tuottaa erottelun tiheämmiksi vuorovaikutusyhteisöiksi kehittyvien kaupunkien ja niitä ympäröivien, harvaan asuttujen alueiden (maatalousyhteiskunnan) välille: solidaarisuuden perustana oleva työnjako on hänen mukaansa "suoraan verrannollinen yhteiskunnan moraaliseen tai dynaamiseen tiheyteen" (emt., 238). Orgaaniselle solidaarisuudelle vastakkaisen mekaanisen solidaarisuuden Durkheim näkee jatkuvasti heikkenevänä ilmiönä ja tyypillisenä historian varhaisemmille yhdyskunnille ja alkuperäiskansoille.

Useimmille tuon ajan tutkijoille edistys tarkoitti vääjäämätöntä kulkua kohti orgaanisen solidaarisuuden sosiaalista järjestystä. Se määrittelee ihmisten välisiä suhteita erityisesti moderneissa kaupungeissa, joissa kasvu, tiheys ja kilpailu eivät vain ohjaa vaan suorastaan pakottavat suurempaan työnjakoon (emt., 242-250). Durkheimin tunnetuista aikalaisista esimerkiksi Max Weber (1864-1920) ja Georg Simmel (1858-1918) seurasivat kaupungistumista tieteellisenä ilmiönä ja kirjoittivat monien muiden kollegojen lailla kaupunkien kulttuurisista ominaispiirteistä (ks. Weber 1992 [1921]; Simmel 2005 [1903]).

Euroopassa kaupunkien vaikutus on kaupunkihistorian professori Peter Clarkin (2009) mukaan ollut erityisen suuri: keskiajalta lähtien Eurooppa on ollut yksi maailman kaupungistuneimmista maanosista. Kaupungit ovat olleet kehityksen moottoreita, erityisesti talouden ja kaupan 
vetovoimaisia keskittymiä, joilla on ollut vahvat kansainväliset verkostot ja liikesuhteet. Mutta vasta teollistumisen myötä kaupungit alkoivat maailmanlaajuisesti kasvaa ja vetää kiihtyvällä tahdilla ihmisiä puoleensa. Teollistumiseen liittyy myös käsitys modernisaatiosta, eli siirtymisestä laajemmin uuteen yhteiskunnalliseen kehitysvaiheeseen.

Kaupungistumisprosessissa on toki nähty myös historiallisia vaiheita, joissa kaupunkeja ja kokonaisia kaupunkikulttuureja on tuhoutunut. Nopea muutos ja voimakas väestönkasvu ovat eri aikoina synnyttäneet kaupungeissa toistuvia kriisejä, vaikeasti hallittavia ongelmia sekä yleistä epäluuloa kaupungistumiskehitystä kohtaan. Sitä onkin eri aikakausina kritisoitu voimakkaasti. Tässä kritiikissä maaseutu on usein liitetty keskusteluun vaihtoehtona tai vastapuolena.

Eräs tunnetuimmista kaupungistumisen kritiikeistä, joissa kaupungin ja maaseudun vastakkainasettelu on noussut esiin, on 1900-luvun teollistumista seuranneen ajan Oswald Spenglerin laaja teos Länsimaiden perikato (Spengler 1996). Aikanaan myyntimenestyksen saavuttaneessa teoksessaan Spengler heijastaa ihmiskuntaa koskevan pessimismin ja edistysuskon romahtamisen kaupungin hahmoon. Hän tulkitsee kaupungin saaneen ylivallan maaseudun sielusta: kaupungit ovat alkaneet määrätä inhimillisen kulttuurin kulkua ja mielekkyyttä tavalla, jolle ei näytä löytyvän vastavoimaa (Jalava 2005). Vastaavia kiistoja löytyy historiasta useita. Yhteistä niille näyttää olevan kritiikki kaupungistumista kohtaan ja maaseudun esittäminen sille vastakkaisena voimana, jossa myös elämäntapa olisi kestävämpi. ${ }^{2}$

Kaupungistuminen synnytti myös tarpeen kasvun suunnitelmalliseen ohjaukseen ja hallintaan. Tärkeä kaupunkien yhteiskunnalliseen merkitykseen liittyvä ilmiö onkin yhteiskunta- ja kaupunkisuunnittelun kehitys. Tähän liittyen voi nostaa esiin kaupunkisuunnittelun arvostetun ja kiistellyn hahmon Lewis Mumfordin (1895-1990). Hän oli pääasiassa historioitsija ja filosofi, mutta hänen ajattelunsa oli hyvin laaja-alaista ja monitieteistä. Vaikka Mumford lähestyi kaupunkeja suunnittelukohteina, häntä voi pitää kaupunkisosiologina, joka yhdistelee analyyseissään eri alojen näkemyksiä. Teoksessaan The Culture of Cities Mumford (1970 [1938]) hahmottaa kaupungin olemusta ja roolia osana modernisoituvan yhteiskunnan kapitalistista tuotantomuotoa. Mumfordin mukaan (emt., 3)

2 Katso aiheesta Suomen kontekstissa Jumppanen 2021 tässä teoksessa. 
historiallisena ja sosiaalisena ilmiönä kaupunki on "yhteisön vallan ja kulttuurin maksimaalinen keskittymä".

Kaupungin ja maaseudun (countryside) yhteen kietoutunutta suhdetta Mumford kuvaa toteamalla, että maaseutu on kaikilla tasoilla osallinen kaupunkien olemassaoloon (emt., 3). Hän näkee niillä siksi myös vahvan kohtalonyhteyden. Mumford painottaakin laajemman näkökulman tärkeyttä ja aluesuunnittelun merkitystä: kaupunki on ymmärrettävä laajemmassa tilallisessa kontekstissaan. Hän oli kiinnostunut myös puutarhakaupungin (Garden Cities) ideasta ja näki arvokkaaksi tavoitella kaupunkisuunnittelussa tasapainoa luonnon ja ympäristön kanssa.

Suhde luontoon on yksi pitkäaikaisimmista kaupunkikeskustelujen teemoista. Kaupungit näyttävät toisaalta manifestoivan ihmisen kykyä ylittää luonnon rajoja, toisaalta elämä kaupungeissakin on väistämättä riippuvainen luonnon kantokyvystä. Kaupungit ovat synnyttäneet erityislaatuisen mahdollisuuden elämäntavalle, jossa luonto ei ole yhtä konkreettisella tavalla läsnä ihmisten elämässä kuin maatalousyhteiskunnissa. Kaupunkitutkimuksen pioneerina tunnettu sosiologi Louis Wirth (18971952) kiteytti kolme tunnetuiksi tullutta kaupungin ja urbaanin elämäntavan avaintekijää: a) väestön määrän, joka tarjoaa anonymiteetin, b) tiheyden, joka mahdollistaa erikoistumisen sekä c) monimuotoisuuden, joka virittää uusia kokemuksia (Wirth 1938).

Kaupunkia voi pitää yhtenä ihmiskunnan vaikuttavimmista sosiaalisista innovaatioista. Kaupunkien kasautuvan kasvun mekanismit ovat osoittautuneet menestystekijöiksi, kun asiaa tarkastelee kaupunkiväestön, talouden ja tuotannon kasvun näkökulmista (mm. Glaeser 2011). Professori Peter J. Taylor kiteyttää teoksessaan Advanced Introduction to Cities (Taylor 2021) historiallisten ja nykyisten kaupunkien analyysin viiteen kaupunkia (city) luonnehtivaan piirteeseen: 1) jatkuva muutosprosessi, 2) toimintojen tihentyminen, 3) vahvat sisäiset yhteydet ja sidokset, 4) vallan ja voiman ilmeneminen sekä 5) suhteet valtioon.

Suurkaupungit ovat globaalin kapitalismin myötä nousseet viime vuosikymmenten aikana hegemoniseen asemaan. Kaupungit ovat läsnä kaikkialla (Taylor 2021, 68). Ne nähdään nykyisin verkottuvina järjestelminä, jotka ovat aktiivisesti vaihdannassa ympäristönsä kanssa. Kaupungistumisen erityispiirteenä on metropolisoituminen. Kymmenien miljoonien asukkaiden metropoleilla on vaikutusta jopa globaalisti. Suurkaupunkien kehitystä ovat kiihdyttäneet tietoteknologiset innovaatiot ja 
alustatalouden synty. Maaseutu määrittyy tässä asetelmassa entistä vahvemmin kaupungeille alisteiseksi, keskenään verkottuvien kaupunkien väliin jääväksi tilaksi, jossa tuotetaan välttämättömiä hyödykkeitä ja palveluja kasvavien kaupunkien kulutukseen.

Talouden muutos tieto- ja osaamisintensiivisempään suuntaan on vahvistanut kaupunkien vetovoimaa ja merkitystä. Talouden vahva nojautuminen tiedon käyttöön (knowledge-based economy) on vahvistanut kaupunkien asemaa sekä suunnannut niihin poliittista kiinnostusta kaikkialla maailmassa (Moisio 2018). Kaupunkien luomista verkottuneista järjestelmistä on tullut taloudellisia ekosysteemejä, jotka vaikuttavat entistä vahvemmin osana maailmantaloutta ja tietoyhteiskuntien rajatonta ihmisten ja alueiden välistä vuorovaikutusta (Haas \& Westlund 2018). Esimerkiksi maataloutta ei tässä katsannossa tarkastella sen maantieteellisen (maaseudulle) sijoittumisen kautta vaan osana kaupunkijärjestelmää palvelevaa arvoketjua.

Kaupunkien kasvun vastavoimat ovat siis olleet suhteellisen heikkoja. Esimerkiksi Kiinassa laajamittainen kaupungistaminen on strateginen tavoite, joka on edennyt viime vuosikymmeninä suunnitelmallisesti. Maan nopea kaupungistuminen on nostanut koko maailman kaupungistumisastetta. Kiinan kaupungeissa asuu nykyisin yli 600 miljoonaa kiinalaista, mikä on 44 \% maan asukkaista (Kamal-Chaoui ym. 2019). Kaupungeissa asuu yhdistyneiden kansakuntien (UN) mukaan nykyisin noin $55 \%$ maailman väestöstä, ja osuuden arvioidaan maailmanlaajuisesti kasvavan vuoteen 2050 mennessä noin 68 prosenttiin (United Nations 2018).

Ajatus maaseudun ja kaupungin vuorovaikutuksen perustumisesta osapuolten tasa-arvoiseen asemaan onkin edellä kuvatun kehityksen myötä muodostunut vaikeammaksi perustella. Yleinen käsitys on, että kaupungistuminen läpäisee yhteiskunnat niin kokonaisvaltaisesti, ettei sille ole uskottavaa vastavoimaa tai vaihtoehtoa. Maaseudut - jos niitä yleensä nähdään tarpeen tunnistaa - ovat tässä katsannossa lähinnä varantoja, joita kaupunkitalous hyödyntää. Maaseutuyhteisöt ovatkin ajautuneet eräänlaiseen puolustusasemaan.

Maaseutujen elinvoima on heikentynyt maaseutuväestön vähenemisen, elinkeinojen yksipuolistumisen ja länsimaissa erityisesti ikärakenteen muutoksen yhteisvaikutuksena. Köyhyyserot ovat maailmanlaajuisesti tasoittuneet, mutta erityisesti niin sanotun globaalin etelän maissa köyhyys on edelleen maaseutuja usein luonnehtiva piirre. 
Maaseuduilla on kuitenkin edelleen merkitystä. Niillä on elintärkeä rooli varsinkin luonnonvaroihin perustuvan tuotannon sekä ihmisten ja luonnon hyvinvoinnin näkökulmasta. Vaikka julkisessa keskustelussa painopiste onkin siirtynyt kaupunkeihin, maaseudun käsite ei ole keskusteluista kokonaan hävinnyt. Maaseutua koskevaa keskustelua käydään edelleen, usein erityisesti yhteiskunnallisen muutoksen kontekstissa. Maaseudut kuvataankin monesti juuri muutosretoriikan kautta. Maaseudun muutosta (rural change) koskevat keskustelut ovat myös tämän tutkimuksen kannalta keskeinen kiinnostuksen kohde.

\section{Maaseudun muutoksen kerrontalinjoja}

Mark Shucksmith ja David L. Brown (2016) nostavat maaseudun muutoksen näkyviksi ja vaikuttaviksi kerronnallisiksi kuvauksiksi kuusi narratiivia, joista käytän seuraavassa myös termiä kerronta tai kerrontalinja. Maaseutu nähdään ensinnäkin maatalouden muutoksen kautta (agri-centric narrative). Tällä narratiivilla on vahva taloudellinen perustansa, ovathan maa- ja metsätalous maaseutujen aluetalouden kannalta edelleen hyvin merkittäviä, ja niiden muutokset näkyvät ja vaikuttavat konkreettisesti erilaisilla maaseuduilla. Luonnonvara-aloihin liittyy monien kansainvälisten ja kansallisten instituutioiden tärkeitä intressejä, joista alan toimijat myös aktiivisesti yhteiskunnassa viestivät. Tässä kerrontalinjassa maaseudun muutos piirtyy tietoisuuteemme luonnonvarojen ja alkutuotannon kautta.

Toisena elävänä kerrontalinjana tutkijat (emt., 5) nostavat esiin juuri kaupungin ja maaseudun vuorovaikutusta kuvaavan kerronnan (urbanrural access narrative). Siinä nousee esiin kaupungistumisen ja kaupunkien kumulatiivisen kasvun pitkän ajan vaikutukset maaseudun asemaan ja elinvoimaan, ja toisaalta alueiden väliset yhteydet, saavutettavuus, virrat ja vastavirrat. Vastakaupungistumisen ilmiö tuottaa tähän kerrontaan liittyvää sisältöä. Oleellista tässä kerrontalinjassa on, että maaseudun muutoksen tulkitaan jäsentyvän kaupungin ja maaseudun monimuotoisen suhteen kautta.

Kansainvälisen kilpailun narratiivissa (competitive economy narrative) maaseudun muutos tuodaan kansainvälisen talouden ja pääomavirtojen vaikutusten kontekstiin. Muutosvoimana on maailmanlaajuisesti liikkuva pääoma, joka etsiytyy hyödyntämään paikallisia resursseja, kuten maata tai työvoimaa. Koska monilla maaseuduilla on heikot edellytykset pitää 
kiinni pääomistaan, ne ovat herkkiä ulkoiselle vaikutukselle ja vallankäytölle. Tähän kerrontaan liittyy myös teknologinen muutos uhkineen ja mahdollisuuksineen. Digitaalinen teknologia ja dataverkot luovat myös edellytyksiä hajautuneemmille toimintatavoille sekä paikallisten yritysten ylipaikalliselle verkottumiselle. Tässä kerrontalinjassa maaseudun muutos ohjautuu kuitenkin vahvasti ulkoisten taloudellisten voimien ja suurten metropolien kautta.

Neljäntenä on historiaan jäävien paikkojen kerrontalinja (places left behind narrative), joka viittaa suomalaisillekin erityisen läheiseen kuvastoon ja kerrontaan maaseudun muutoksesta. Suomessa rakennemuutos oli erityisen nopeata toisen maailmansodan jälkeen. 1960-1970 -lukujen suuri muuttoliike tuotti sadoille tuhansille suomalaisille kokemuksen maaseudusta, joka jäi konkreettisesti taakse elämän suuntautuessa toisaalle. Nopea rakennemuutos synnytti kasvukipuja kaupungeissa mutta sitoi samalla monien muistot ja kaipuun maaseuduille. Paikkasidoksia voitiin toisaalta myöhemmin palauttaa mieliin esimerkiksi mökkeilyn kautta. Kehityksen kerronnallinen kuvaaminen liikkeenä "jostakin vanhasta johonkin uuteen" on edistysretoriikassa paljon käytetty, ja siihen voivat yhdistyä myös paikkojen kuvaukset.

Viidentenä tutkijat (emt., 6) ovat tunnistaneet mielihyvää tuottavan palvelusektorin tuomaan muutokseen perustuvan narratiivin (amenity based economy narrative). Siinä taloudellisesti hyvin toimeentulevat ihmiset hakevat maaseuduilta laadukkaita tuotteita ja palveluja. Kokemuksia tarjoavat esimerkiksi luonnonpuistot, laskettelukeskukset tai matkailukohteet, mutta myös ruoka ja muut elämykset. Tämä kysyntä luo maaseuduille luonnollisesti uusia mahdollisuuksia, mutta myös muuttaa luonnonympäristöä ja paikallisia elinkeinoja. Tässä kerrontalinjassa maaseudun muutos syntyy erityisesti siitä, kun laajat ihmis- ja kuluttajaryhmät kaupungeissa kiinnostuvat maaseudusta kuluttamisen kohteena.

Lopuksi Shucksmith ja Brown $(2016,7)$ tuovat esiin hyvin pitkäaikaisen kerrontalinjan, eli yhteiskunnan ja luonnon keskinäisriippuvuutta koskevan narratiivin (narrative of society-nature interrelationships). Se perustuu kaiken ihmistoiminnan ja talouden vastavuoroiseen suhteeseen luonnon kanssa ja siinä yhdistyvät monet edellä esitetyt kerronnalliset elementit. Keskeinen teema on voimallista luonnonvarojen käyttöä seuraava muutos, kuten maa- metsä- ja kaivannaistalouden sekä syventyvän maailmanlaajuisen taloudellisen kilpailun jättämät jäljet luonnonympäristöön ja paikallistalouksiin. Tässä yhteydessä kirjoittajat nostavat esiin 
myös ilmastonmuutoksen, joka on nousemassa merkittäväksi maaseutuja koskettavia kehittämispolitiikkoja määrittäväksi tekijäksi. Esimerkiksi hiilijalanjälkeä arvioitaessa korostuu kysymys eri sektoreiden kestävyysratkaisujen mittakaavasta sekä ratkaisujen hajautumisen asteesta.

Edellä mainittuihin kytkeytyvänä mutta erikseen maininnan arvoisena kerrontalinjana on perusteltua nostaa esiin historiallinen ja pitkävaikutteinen poliittis-hallinnollinen narratiivi. Se tarkoittaa erityisesti julkisen vallan edustajien, viranomaisten ja poliitikkojen ylläpitämää keskustelua, jossa kaupunki ja maaseutu ovat suhteellisen tarkasti määriteltyinä ja oikeutettuina esillä. Tästä kerrontalinjasta ovat esimerkkeinä kaupunkien ja maaseutujen määrittely tilastollisina ja hallinnollisina yksiköinä, oikeudellisina toimijoina tai politiikkatoimenpiteiden kohdealueina.

Keskeinen peruste poliittis-hallinnolliselle kerronnalle on julkisen vallan alueellinen ja paikallinen organisoituminen. Valtiolla on julkista valtaa käyttävänä instituutiona legitiimi oikeus käyttää valtaansa tietyllä maantieteellisellä alueella. Kaupungit ja alueet ovat kautta kansallisvaltioiden historian olleet osa valtioiden hallinto- ja valtajärjestelmää. Mutta kyse ei ole vain hallinnan instituutioista, vaan myös laaja-alaisesta ja monitasoisesta kerrontalinjasta, joka osaltaan ylläpitää kuvaa maaseudusta ja kaupungista.

\section{Suomen maaseudut ja kaupungit julkishallinnon määrit- teleminä}

Poliittis-hallinnollisessa kerronnassa on luontevaa esittää kaupunki toimijana tai päättäjänä. Maaseudusta ei puhuta näin, koska se ei samassa merkityksessä ole toimija. Tässä kerronnassa maaseutu on päinvastoin yleensä toimenpiteiden kohde. Maaseutua koskevat päätökset mielletäänkin usein tehtävän jossain muualla, yleensä siellä, missä julkisen hallinnon toimipaikatkin pääasiassa ovat, eli kaupungeissa. Suomen nykyisessä hallintojärjestelmässä kaikki kaupungit ja muut paikallisen itsehallinnon yksiköt ovat kuntia. Ne voidaan ymmärtää myös toimijoina.

Kaupungeilla on oma pitkä valtiojärjestelmään liittyvä hallinnollinen historiansa, jonka osana kaupungeille jaettiin sekä oikeuksia että velvollisuuksia. Vielä 1970-luvulle saakka Suomessa oli erikseen kaupunkeja, kauppaloita ja maalaiskuntia. Vuoden 1977 kuntalain uudistuksen myötä 
kaikkia kuntia alettiin lainsäädännössä nimittää samalla tavalla kunniksi. Kaupunki- ja maaseutualueiden erilainen kohtelu säilyi kuitenkin esimerkiksi rakennuslaissa aina 1990-luvulle asti. Nykyisin kunta voi omalla päätöksellä ottaa kaupunki -nimityksen käyttöön. Tällä hetkellä (2021) Suomessa on kaikkiaan 309 kuntaa, joista 107 käyttää itsestään nimitystä kaupunki. Suomen pienin kaupunki on 1246 asukkaan Kaskinen ja suurin on pääkaupunki Helsinki, jonka asukasluku on noin 653000 (Kuntaliitto 2021).

Alueiden virallisessa luokittelussa tapahtui 2000-luvulla merkittävää edistystä, kun kuntatasoisesti kootuista tunnusluvuista siirryttiin paikkatietoihin ja ruutuperusteiseen (250x250 m) tilastointiin. Kaupunki-maaseutu -luokituksessa tilastoruutupohjaiseen luokitteluun siirryttiin 2013. Tämä on tehnyt mahdolliseksi tutkia maaseutu- ja kaupunkialueiden määrittelyä hallinnollisista rajoista riippumattomasti. Suomen kansallisen alueluokituksen perusteella maa on nykyisin luokiteltu seuraavasti:

- sisempi kaupunkialue

- ulompi kaupunkialue

- kaupungin kehysalue

- kaupungin läheinen maaseutu

- maaseudun paikalliskeskukset

- ydinmaaseutu ja

- harvaan asuttu maaseutu.

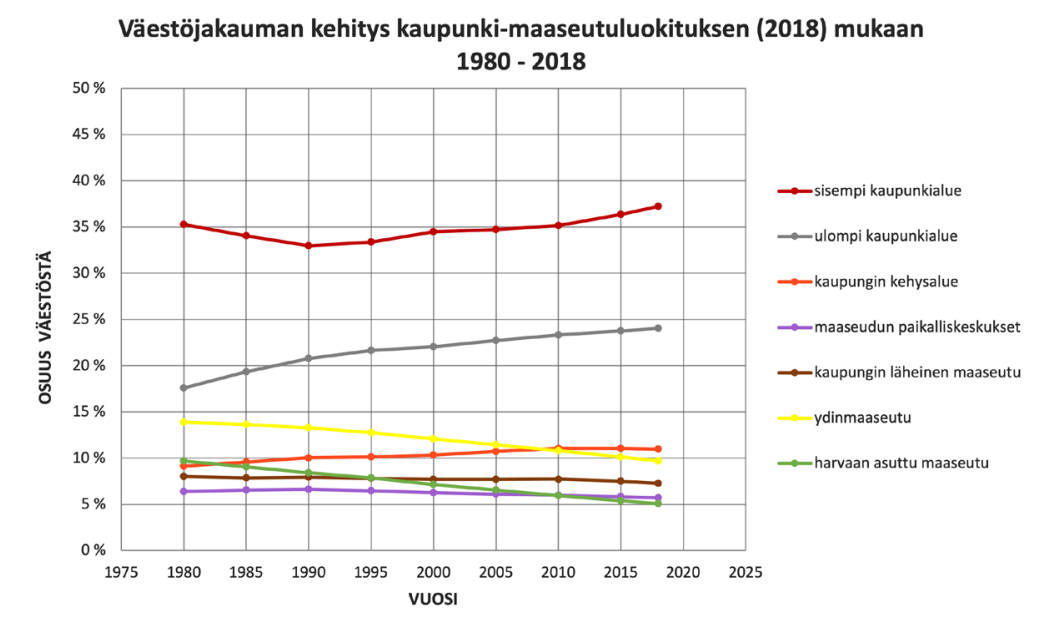

Kuva 1. Suomen väestön jakautuminen kaupunki-maaseutu -luokituksen mukaisesti 19802020 (Suomen ympäristökeskus). 


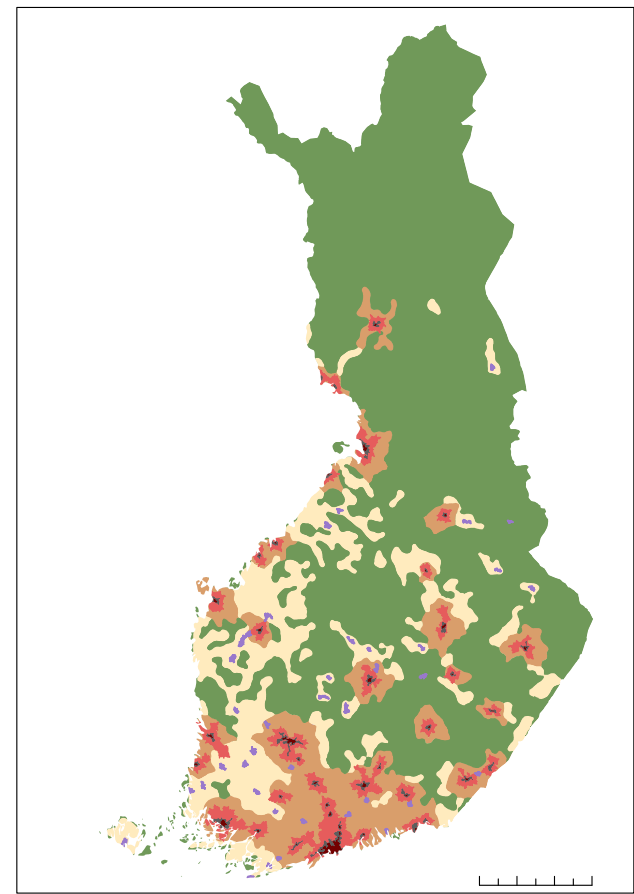

\section{Kaupunki-maaseutuluokitus (2018)}

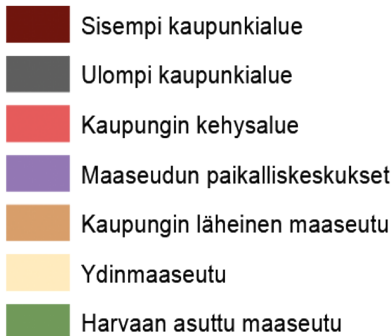

Kuva 2. Suomen nykyinen (2018) kaupunki-maaseutuluokitus (Suomen ympäristökeskus).

Tämä luokittelu on viimeksi päivitetty Suomen ympäristökeskuksessa vuoden 2018 tiedoilla (Helminen ym. 2020). Sen perusteella 72 prosenttia suomalaisista asui tuolloin kaupunkialueilla.

Luokkien nimityksistä on aika ajoin keskusteltu ja muuttujia kehitetty. Perusteiltaan luokittelu on kuitenkin pysynyt suhteellisen samana. Lähtökohtaisesti se perustuu sekä ihmisten vakituiseen asuinpaikkaan (kotipaikka) että kaupungin ja maaseudun ymmärtämiseen eräänlaisena maantieteelliseen kontekstiin sijoittuvana jatkumona, jossa rajat määrittyvät erilaisten tilastollisten muuttujien suhteellisina osuuksina tilastoruuduittain. Ydinmaaseutu ja harvaan asuttu maaseutu määritellään väentiheyden, maankäytön intensiteetin sekä alueella asuvien työllisten toimialojen monipuolisuuden perusteella (Helminen ym. 2014, 32-44).

Uusimman luokituksen rajojen muutokset ovat 2010 tilanteeseen verraten pieniä, joskin hienoista aluetyyppien suhteiden muutosta voidaan havaita: pinta-alaltaan eniten ovat laajentuneet kaupungin kehysalue ja kaupungin läheinen maaseutu, mikä kertoo osaltaan kaupunkien vaikutusalueiden kasvusta (ks. Helminen ym. 2020). Luontoalueita tämä 
luokittelu ei erikseen huomioi, vaan ne ovat luokitusten sisällä, ja esimerkiksi harvaan asutun maaseudun luokka sisältää laajoja erämaa-alueita.

Viralliset tilastot perustuvat edelleen pääasiassa ihmisten ja muiden toimijoiden rekisteröityihin kotipaikkoihin, eli luvuissa ei näy ihmisten liikkuminen alueiden välillä. Tällä on luonnollisesti vaikutusta siihen, millainen kuva alueista tilastojen kautta syntyy ja millaisia mielikuvia nämä viralliseen tilastointiin perustuvat kuvaukset synnyttävät. Viime vuosina on saatu laajemmin käyttöön myös uusia aineistoja, kuten matkapuhelindataa sekä muuta liikkuvuus- tai kulutusdataa. Niiden perusteella on voitu tuottaa monipuolisempia aluekuvauksia. Keskusteluun on noussut erityisesti vapaa-ajan asukkaiden viettämä aika mökkipaikkakunnilla. Tilastollinen leikkauskuva kesäajan Suomesta onkin väestön sijoittumisen näkökulmasta toisenlainen kuin tarkasteltaessa tilannetta talven kuukausina (Adamiak ym. 2017; Lehtonen \& Vihinen 2020). Tämä keskustelu ilmentää hyvin maaseudun ja kaupungin välisen suhteen dynamiikkaa.

\section{Maaseudun ja kaupungin vuorovaikutus keskusteluna}

Edellä esitetyt maaseudun muutosta kuvaavat kerrontalinjat kytkeytyvät monisäikeisesti ja erottamattomasti kaupunkeihin. Mutta ne liittyvät läheisesti myös vallan, toimijuuden ja hallinnan kysymyksiin: kerronta ja kuvaukset ovat osa vallan tavoittelua, toimijuuksien synnyttämistä sekä hallintaa. Niiden kantaminen on myös aktiivisen valinnan kysymys. Kerrontalinjat tarjoavat mahdollisuuden myös politiikan tekemiseen ja vaikuttamiseen.

Maaseudun ja kaupungin suhdetta kuvaava kerronta on avointa myös kansalaisten ja muiden toimijoiden osallistua. Kaupungin ja maaseudun vuorovaikutus ei näin ajateltuna ole vain taloudellista vaihdantaa tai verkostoissa tapahtuvaa materiaalin liikettä, vaan se on myös elävä keskustelu, jossa maaseudun ja kaupungin vuorovaikutus määrittyy ja kehittyy.

Kuvan 3 asetelmassa olen hyödyntänyt Keith Halfacreen (2006; 2007) kehittämää jäsennystä maaseudun tilallisesta konstruoitumisesta fyysisen, toiminnallisen, kuvitellun ja kuvatun (representoidun) tilan välisissä suhteissa. Tämä jäsennys sopii nähdäkseni yhtä hyvin kaupunkitilan hahmottamiseen. Mutta tässä yhteydessä nostan sen perustelluksi tavaksi 


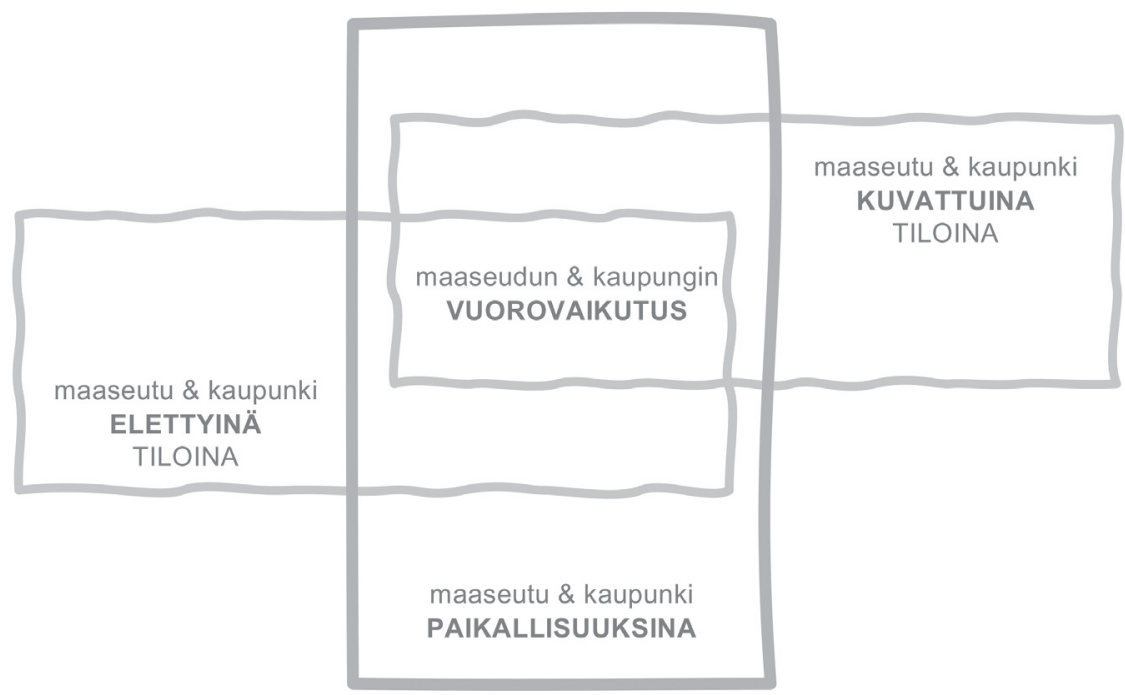

Kuva 3: Maaseudun ja kaupungin vuorovaikutuksen näkökulmia koostava yleinen kehys

hahmottaa myös kaupungin ja maaseudun vuorovaikutusta koskevaa keskustelua.

Kuvan 3 asetelmassa maaseudun ja kaupungin vuorovaikutus jäsentyy moniäänisenä keskusteluna, jossa risteää kolme erilaista maaseudun ja kaupungin suhteen ulottuvuutta: 1) maaseutujen ja kaupunkien luonne havaittavina, maantieteellisesti rajautuvina paikallisuuksina ja yhdyskuntina, 2) maaseutu ja kaupunki elettyinä, kokemuksellisina todellisuuksina ja tiloina sekä 3) maaseutu ja kaupunki representaatioina ja kuvattuina tiloina.

Maaseudun ja kaupungin vuorovaikutus voidaan kuvan 3 mukaisesti nähdä kohteena, jossa vaikuttavat yhdenaikaisesti kolme hyvin erityyppistä ulottuvuutta. Nähdäkseni maaseudun ja kaupungin vuorovaikutusta onkin käytännössä mahdotonta tutkia tai kuvata kokonaisuutena: tutkijoiden on tehtävä valinta ja kohdistettava analyysi pääasiassa jonkun ulottuvuuden mukaisesti. Tämän jälkeen myös muiden näkökulmien huomioon ottaminen on mahdollista. 


\section{Kaupungin ja maaseudun vuorovaikutus sanomalehti- kerronnassa}

Tässä julkaisussa kaupungin ja maaseudun vuorovaikutusta on tarkasteltu sanomalehdissä tuotetun kerronnan näkökulmasta. Maaseudun ja kaupungin vuorovaikutusta voidaan tällä abstraktion tasolla analysoida käytännössä juuri kirjoitetun kielen, eli dokumentoitujen keskustelujen kautta. Sanomalehdissä julkaistut tekstit voidaan tulkita yhteiskuntaelämän päiväkirjamaisina, jaettuina kuvauksina, jossa kerrontaa tuotetaan eri näkökulmista sosiaaliseen keskusteluavaruuteen jatkuvana virtana.

Julkaisun tutkimusartikkelit pureutuvat kukin rajatusta näkökulmasta näihin keskusteluihin ja niissä esitettyyn argumentointiin pyrkien jäsentämään siitä tulkintaa maaseudun ja kaupungin elävästä suhteesta. Kaikissa tapauksissa tutkitun keskustelun taustalta voidaan tunnistaa yhteiskunnallisia muutoksia, jotka ovat aikaansaaneet yhteiskunnallista liikehdintää ja synnyttäneet myös jännitteitä asioiden, intressien ja arvojen sekä ihmisten ja ihmisryhmien välille. Keskustelujen taustalta voidaan usein tunnistaa myös pyrkimyksiä käyttää jotain kerrontalinjaa vallan tai hallinnan välineenä.

Yhteiskunnat ovat jatkuvan muutoksen tilassa ja muutokset kohdistuvat eri ihmisryhmiin eri tavoin. Muutoksilla on aina myös voimaltaan ja vaikutuksiltaan vaihtelevia paikallisia, niin ennakoitavia kuin ennakoimattomiakin seurauksia. Tästä syystä muutoksia koskevat keskustelut muotoutuvat usein sen mukaan, keitä niiden odotetaan eniten koskevan, ja missä muutosten paikallisten vaikutusten oletetaan tai koetaan olevan suurimmat. Yleisenä asetelmana tämän voi kuvata yksinkertaistaen kuvan 4 tapaan.

Kuva 4 havainnollistaa, miten maaseudun ja kaupungin vuorovaikutuksen rakentuminen julkisissa keskusteluissa voidaan yleisellä tasolla hahmottaa muodostuvan: a) yhteiskunnallisten muutosten aiheuttamasta liikkeestä, joka b) synnyttää toimijasuhteissa jännitteen, joka ilmenee c) julkisessa keskustelussa, jossa d) muutosta merkityksellistetään. Lopulta keskustelu kytkeytyy jatkuvaan muutokseen ja vaikuttaa sen suuntautumiseen.

Maaseudun ja kaupungin vuorovaikutus on näin ymmärrettynä elävä ja muuntuva keskustelu, jossa nämä entiteetit asettuvat (ja asetetaan) 


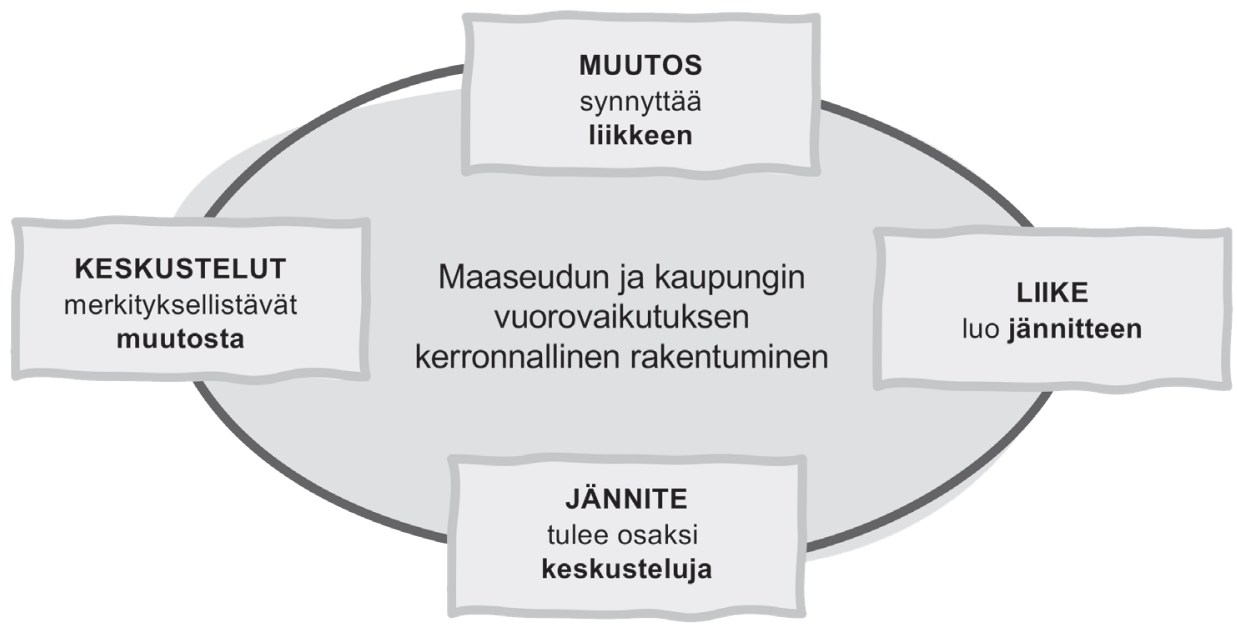

Kuva 4: Maaseudun ja kaupungin vuorovaikutuksen kerronnallinen rakentuminen

jostain valitusta näkökulmasta suhteessa toisiinsa. Tämä suhde voidaan rakentaa ja esittää myös juonellisena tarinana, jossa on enemmän tai vähemmän selkeä viesti. Yksittäiset kuvaukset koostuvat laajemmaksi kerronnaksi ja kuvastoksi, joista esimerkkejä kuvailtiin edellä.

\section{Osatutkimusten kohdentuminen maaseudun ja kaupungin vuorovaikutukseen}

Ensimmäisessä tutkimusartikkelissa Antti Kanner ja Torsti Hyyryläinen tutkivat, miten maaseutu ja kaupunki jäsentyvät vastakkaisiksi kategorioiksi kielen tasolla. Kielijärjestelmän kokonaisuus vaikuttaa siihen, miten kieltä ja sanoja käytetään sekä miten niiden merkitykset ymmärretään. Tämä kielen muutos kytkeytyy monimutkaisesti samanaikaisiin yhteiskunnallisiin muutoksiin ja pyrkimyksiin ottaa maaseudun käsite aktiivisen identiteettipolitiikan rakennusaineeksi ja vallantavoittelun välineeksi.

Aapo Jumppanen analysoi Maaseudun Tulevaisuus -lehdessä esitettyjä kuvauksia maaseutu- ja kaupunkielämästä moraalisina konstruktioina. Tuona ajankohtana lehti etsi ja esitteli perusteita maalaiselämän puolesta ja varoitteli kaupunkilaiselämän vaaroista. Samalla se tuotti vahvasti vastakkaisia kuvauksia ja lisäsi jännitteitä maaseudun ja kaupungin suhteita koskevaan yleiseen keskusteluun. Tutkimus on osuva kuvaus 1900-luvun 
alun kehityksestä, jolloin maaseutu-käsite otettiin laajasti myös poliittiseen käyttöön.

Eeva Uusitalon tutkimus kohdistuu maaseudun ja kaupungin suhteen jäsentymiseen pienen kehittyvän kaupungin markkinoita koskevassa julkisessa keskustelussa. Uusitalo kuvaa, miten ihmiset kohtaavat markkinoilla tuottaen samalla kaupungille tyypillistä monimuotoisuutta ja ristiriitaisuutta. Tutkimus osoittaa, miten maaseudun ihmiset tekevät kaupunkitilasta elävän markkinapaikan, joka samalla ilmentää kaupungin erityisluonnetta ja ilmapiiriä. Erilaisten ihmisten kohtaamisissa syntyy ristiriitoja ja jännitteitä, joista sanomalehdissä raportoidaan aktiivisesti maalaisten ja kaupunkilaisten eroina, moraalisia kannanottoja välttelemättä. Samalla tuotetaan käsitystä sekä maaseudun asukkaista (maalaisista) että kaupunkilaisista itsestään.

Manu Rantanen nostaa tutkimuskohteeksi kuvaukset monipaikkaisista ihmisistä, jotka jakavat aikansa kaupungin ja maaseudun välillä ja pitävät käytännössä yllä maaseutujen ja kaupunkien elävää vuorovaikutusta. Monipaikkaiset asukkaat eivät ole yhtenäinen ryhmä, vaan heidän kokemuksensa maaseudun ja kaupungin eroista ovat hyvin yksilöllisiä. Sanomalehtien sivuilla heidät asetetaan kuitenkin osaksi erilaisia kerrontalinjoja, jotka irtautuvat ihmisten omasta kokemusmaailmasta. Kuvauksista tulee näin osa merkityskampailuja ja vaikuttamista, joka pyrkii hyödyntämään ihmisten monipaikkaisuutta omiin tarkoitusperiinsä. Erilaiset tavoitteet - ja samalla tavat kertoa monipaikkaisista asukkaista - ovat vaihtuneet vuosikymmenten aikana paljonkin.

Julkaisun yhteisessä loppuluvussa teemanumeron kirjoittajat pohtivat katse tulevaan suuntautuen, millaiset yhteiskunnalliset voimat ja muutokset tässä ajassa vaikuttavat maaseudun ja kaupungin vuorovaikutukseen ja millaisiin suuntiin se voisi näköpiirissä olevien muutosten virrassa kehittyä. Ruuan ekologian ja yhteisen hyvinvoinnin (One Wellbeing) käsitteen näkökulmista loppuluvun kirjoittamiseen osallistui myös Juha Helenius. Tulevaisuudessa ilmastonmuutoksen hillintä ja muut kestävyysmuutoksen teemat nousevat todennäköisesti tärkeiksi virikkeiksi maaseudun ja kaupungin vuorovaikutusta koskeviin keskusteluihin. Jännitteetön ei tuokaan aihepiiri tule olemaan. 


\section{Kirjallisuus}

Adamiak, Czesław, Kati Pitkänen \& Olli Lehtonen 2017. Seasonal residence and counterurbanization: the role of second homes in population redistribution in Finland. GeoJournal 82(5): 1035-1050.

Clark, Peter 2009. European Cities and Towns 400-2000. Oxford University Press.

Durkheim, Émile 1990. Sosiaalisesta työnjaosta. Gaudeamus. [Alkup. 1893, suomennos Seppo Randell]

Glaeser, Edward 2011. Triumph of the City. How Our Greatest Invention Makes Us Richer, Smarter, Greener, Healthier, and Happier. Penquin Press.

Haas, Tigram \& Hans Westlund (eds.) 2018. In the Post-Urban World. Emergent Transformation of Cities and Regions in the Innovative Global Economy. Regional Studies Association. Routledge. Taylor \& Francis Group.

Halfacree, Keith 2006. Rural space: constructing a three-fold architecture. Teoksessa Cloke, Paul, Terry Marsden \& Patrick Mooney (eds.). Handbook of Rural Studies, Sage, London, 44-62.

Halfacree, Keith 2007. Trial by space for a "radical rural": Introducing alternative localities, representations and lives. Journal of Rural Studies 23, 125-141.

Helminen, Ville, Kimmo Nurmio \& Sampo Vesanen 2020. Kaupunki-maaseutu-alueluokitus 2018. Suomen ympäristökeskuksen raportteja 21. Suomen ympäristökeskus.

Helminen Ville, Kimmo Nurmio, Antti Rehunen, Mika Ristimäki, Kari Oinonen, Maija Tiitu, Ossi Kotavaara, Harri Antikainen \& Jarmo Rusanen 2014. Kaupunki-maaseutualueluokitus. Paikkatietoihin perustuvan alueluokituksen muodostamisperiaatteet. Suomen ympäristökeskuksen raportteja 25. Suomen ympäristökeskus.

Jalava, Marja 2005. Ikuinen talonpoika ja kivierämaan nomadit - maaseudun ja kaupungin vastakohtaisuus Oswald Spenglerin Länsimaiden perikadossa. Teoksessa Joutsivuo, Timo \& Markku Kekäläinen (toim.), Kaupunkikuvia ajassa. SKS. Historiallinen Arkisto 119. Vammala. 261-298.

Joutsivuo, Timo \& Markku Kekäläinen 2005. Kaupunki historian kuvastimessa antiikista 1900-luvun alkuun. Teoksessa: Joutsivuo, T. \& M. Kekäläinen (toim.) Kaupunkikuvia ajassa. SKS. Historiallinen Arkisto 119. Vammala. 9-24.

Jumppanen, Aapo 2021. Maaseutu on kaupungin äiti - Maaseudun ja kaupungin vastakkainasettelu Maaseudun Tulevaisuuden sivuilla 1916-1918. Teoksessa Hyyryläinen, Torsti \& Kaisa Schmidt-Thomé (toim.). Maaseudun ja kaupungin elävä suhde. Maaseutututkimus, vol. 29 Teema. 67-98. https://doi.org/10.51807/ maaseutututkimus. 112888

Kamal-Chaoui, Lamia, Edward Leman \& Zhang Rufei 2019. Urban Trends and Policy in China. OECD Regional Development Working papers 1/2019.

Kanner, Antti \& Torsti Hyyryläinen 2021. Maaseutu-sanan semanttinen käänne ja merkityksen muotoutuminen. Teoksessa Hyyryläinen, Torsti \& Kaisa Schmidt-Thomé (toim.). Maaseudun ja kaupungin elävä suhde. Maaseutututkimus, vol. 29 Teema. 33-65. https://doi.org/10.51807/maaseutututkimus.112887

Kuntaliitto 2021. Kaupunkien ja kuntien lukumäärät ja väestötiedot. Saatavilla: https://www. kuntaliitto.fi/tietotuotteet-ja-palvelut/kaupunkien-ja-kuntien-lukumaarat-javaestotiedot (luettu 2.11.2021) 
Lehtonen, Olli \& Hilkka Vihinen 2020. Kohti kestävää monipaikkaista yhteiskuntaa. Maaseutututkimus 1/2020. 103-111. https://journal.fi/maaseutututkimus/article/ view/94489 (luettu 23.11.2021)

Moisio, Sami 2018. Geopolitics of the Knowledge-Based Economy. Regional Studies Association. Routledge.

Mumford, Lewis 1970. The Culture of Cities. A Harvest/HBJ Book. [Alkup. 1938.] Paavilainen, Matti 1972. Kaupunki on enemmän kuin kohtalo. Kirjayhtymä. Helsinki.

Pyysiäinen, Jarkko \& Hilkka Vihinen 2020. Maaseutubarometri 2020. Tutkimusraportti osa 1. https://www.maaseutupolitiikka.fi/uploads/MANE-raportit/Maaseutubarometri-2020osa-1.pdf (luettu 23.11.2021)

Shucksmith, Mark \& David L. Brown 2016. Framing Rural Studies in the Global North. Teoksessa Shucksmith, Mark \& David L. Brown (eds.). Routledge International Handbook of Rural Studies. Routledge. 1-26.

Simmel, Georg 2005. Suurkaupunki ja moderni elämä. Kirjoituksia vuosilta 1895-1917. Suomentanut Tiina Huuhtanen. Valikoinut ja esipuheen kirjoittanut Arto Noro. Gaudeamus, Helsinki. [Alkup. 1903.]

Spengler, Oswald 1921. Der Untergang des Abendlandes, Bd. 1: Gestalt und Wirklichkeit. Munchen: Beck.

Spengler, Oswald 1996. Länsimaiden perikato. Maailmanhistorian morfologian ääriviivojaLyhennetty laitos, 2. korjattu painos. suom. Yrjö Massa. WSOY. Juva.

Taylor, Peter J. 2021. Advanced Introduction to Cities. Edward Elgar Publishing.

United Nations 2018a. Department of Economic and Social Affairs. Saatavilla: https://www. un.org/development/desa/en/news/population/2018-revision-of-world-urbanizationprospects.html (luettu 2.11.2021)

United Nations 2018b. The Worlds's Cities in 2018. Data Booklet.

Weber, Max 1992. Kaupunki. Vastapaino. Jyväskylä. [Alkup. 1921.]

Wirth, Louis 1938. 'Urbanism as a way of life', American Journal of Sociology 44. 3-24. 